\title{
Improving the ability of the students in providing excellent service by using learning video based on character education
}

\author{
Eva Mirza Syafitri ${ }^{1}$, Hifzhan Frima Thousani ${ }^{2}$, Imam Basuki ${ }^{3}$, Netty Lisdiantini ${ }^{4}$, \\ Tri Lestariningsih ${ }^{5}$, Aminudin Azis ${ }^{6}$
}

State Polytechnic of Madiun, Madiun 1,2,3,4,5,6

\{evamirzas@pnm.ac.id\}

\begin{abstract}
Character education in the excellent service course is very important because in the prime service course students must be able to provide the best service. Students belong to the category mature so that the character has been formed. Character education for the adult level is only limited to strengthening and raising awareness in oneself. Based on my previous research, in 2019 character education based on local wisdom has been able to improve student service abilities, but with conventional delivery, students are a bit difficult to understand the Javanese philosophy being taught. Based on this, learning media such as instructional videos are needed, so this research aims to facilitate students in the character education process based on local wisdom. The object of this research is students of the Madiun State Polytechnic of Business Administration who are currently taking excellent service courses. This research method is a quasi-experimental form of "Non Equivalent Control Group Design". Where the researchers took one experimental class and one control class. This study used a non-parametric analysis with the chi square method and the contingency coefficient of SPSS.21 assistance on the crosstab menu. The results of this study indicate that the use of audio-visual learning models has an effect on improving the ability to serve students. The magnitude of the influence of the use of the audiovisual learning model on improving the ability to serve students is $43.3 \%$
\end{abstract}

Keywords: Character education, excellent service course, Learning with videos, effectiveness of video media

\section{Introduction}

Character buildings must continue to be carried out holistically from all educational environments, namely family, school, and community. Character education itself is carried out by habituating to positive behavior and avoiding negative behavior. Character education needs to be a part of learning in primary school to higher education. In higher education, of course, it is different from how to carry out character education in school. Character education for adults, especially students, is appropriate through increasing the awareness for positive behavior and self-evaluation [1]. 
Character education is more effective when it comes from one's own awareness, not from the influence of others. The forms of character education include: lectures and recitation, adopting the theme of character education in seminar forums, discussions, mass media, films, writing scientific works with the theme of character education, learning from other people's life experiences, etc. Therefore, it is very important for every educator to find the most appropriate way how to instill character education in each subject [2]. The Excellent Service Course is a compulsory subject that must be taken by students of the Madiun State Polytechnic, Business Administration study program. This course aims to educate students to be able to provide excellent service to customers. Of course, this course does not only expect students to know in an understanding way, but also to cultivate the character of excellent service attitudes in students.

Based on previous research that I have done, character education based on a local wisdom in the prime service course shows an increase in the ability of the students to serve by $20 \%$.[3] However, in this study, there are several notes to be highlighted, for instance the media used were only through power points and direct explanations from lecturers. There is a need for interactive learning media such as videos so that the students can easily understand the character education based on the local wisdom. Through the videos, students will respond to what they see and hear.[4]

According to the founding, this interactive video can be considered as as a learning trigger or stimulation so that students are interested in learning, do not feel bored with the learning process, and will be able to capture the material faster. Thus, it is important to do a further research in order to find the best solution in learning problems of excellent service, especially the use of learning media, to create maximum learning outcomes for the students. The purposes of this research are too know the effect of using instructional videos in improving student service abilities, and to know the magnitude of the use of instructional videos in improving student service abilities

\section{Methods}

The research method used Quasi Experimental Design, namely experimental research design, which is the development of true experimental design, through the Nonequivalent Control Group Design. The research design, which was carried out in the form of a Quasi Experimental Design, is devoted to the form of "Non Equivalent Control Group Design". This design used experimental and control groups who were not taken randomly, but the two selected homogeneous groups. The experimental group referred in this study was a group of students who learnt with video learning media by planting character education based on the local wisdom in the prime service subject, 30 students selected from Class $3 \mathrm{~A}$, while the control group was the group that got character education learning based on the local wisdom, 30 students selected from Class 3B.

Before being given different treatment, each group was given a test to measure the initial mathematical understanding of each student in the two groups, and after that, each group was given a post-test to compare with the pretest results. In this study, it is hoped that the researcher will produce a description of the results regarding "The Effectiveness of the use of instructional videos in improving the ability of excellent service college student". This design used two groups of objects that are selected in a symbolic way. The experimental group was given treatment in learning using media while the control group was given treatment in learning 
without using audio video media as routine learning activities. In order to make this research design clearer, it is described as follows:

Table 1. Research design

\begin{tabular}{ccccc}
\hline & & \multicolumn{3}{c}{ Ability to Serve } \\
\cline { 3 - 4 } Class & Conventional & & & \\
& failed & Less & enough & Well \\
\hline
\end{tabular}

To answer this research question, a non-parametric analysis was used with the chi square method and the SPSS.21 assisted contingency coefficient on the crosstab menu. The results of this study were in the form of student assessment data after using practical test instruments. This practice instrument was tested first to determine the validity and reliability of each indicator of the assessment points. The flow and division of tasks in this study can be seen in Table 1 .

\section{Results and Discussions}

\subsection{Research Instrument Testing}

Testing the research instrument consists of two stages, namely the validity and reliability test where these testing stages are carried out to produce the right instrument to measure what is expected.

\section{a) Validity test}

The instrument in this study consisted of a learning outcome test instrument and a professional attitude. The learning outcome test instrument consists of 25 questions. Of these 25 items were analyzed using the product moment correlation formula and the calculations were assisted by the SPSS.9.0 computer program, it can be stated that the 25 items were declared valid.

\section{b) Reliable test}

The reliability test of each of the research instruments used the Hoyt technique because the dichotomous nature of the data resulted in a value of $F=1.8886$ with a significance $=0.0065$ $<0.05$, meaning that the valid learning outcome test items were said to be reliable.

\subsection{Results of Data Analysis}

In the process of analyzing this data, it is divided into two, namely data description and followed by hypothesis testing.

\section{a) Data Description}

Before stepping into the hypothesis testing process, the distribution of data is presented according to the objectives of the analysis as follows:

Table 2. Research data distribution 
Klp * K lyni Crosstabulation

\begin{tabular}{ccccccc}
\hline & & \multicolumn{4}{c}{ K_lyni } & Total \\
\cline { 3 - 6 } & & failed & Less & enough & well & \\
\hline Klp knvs & Count & 8 & 9 & 8 & 4 & 29 \\
& \% within Klp & $27.6 \%$ & $31.0 \%$ & $27.6 \%$ & $13.8 \%$ & $100.0 \%$ \\
& \% within K_lyni & $100.0 \%$ & $52.9 \%$ & $47.1 \%$ & $23.5 \%$ & $49.2 \%$ \\
& \% of Total & $13.6 \%$ & $15.3 \%$ & $13.6 \%$ & $6.8 \%$ & $49.2 \%$ \\
Ekp1 & Count & 0 & 8 & 9 & 13 & 30 \\
& \% within Klp & $0.0 \%$ & $26.7 \%$ & $30.0 \%$ & $43.3 \%$ & $100.0 \%$ \\
& \% within K_lyni & $0.0 \%$ & $47.1 \%$ & $52.9 \%$ & $76.5 \%$ & $50.8 \%$ \\
Total & \% of Total & $0.0 \%$ & $13.6 \%$ & $15.3 \%$ & $22.0 \%$ & $50.8 \%$ \\
& Count & 8 & 17 & 17 & 17 & 59 \\
& \% within Klp & $13.6 \%$ & $28.8 \%$ & $28.8 \%$ & $28.8 \%$ & $100.0 \%$ \\
& \% within K_lyni & $100.0 \%$ & $100.0 \%$ & $100.0 \%$ & $100.0 \%$ & $100.0 \%$ \\
& \% of Total & $13.6 \%$ & $28.8 \%$ & $28.8 \%$ & $28.8 \%$ & $100.0 \%$ \\
\hline \multicolumn{6}{c}{ Source: output SPSS.21.0 processed data } &
\end{tabular}

It can be seen in the table above that in the conventional class Kempok there are: $8(27.6 \%)$ students in the failed category, $9(31.0 \%)$ students in the poor category, $8(27.6 \%)$ students in the sufficient category, and $4(13.8 \%)$ students are in good category. Experimental class contained: there were no students in the failed category, $8(26.7 \%)$ students in the poor category, $9(30.0 \%)$ students in the enough category, and $13(43.3 \%)$ students in the good category.

\section{b) Chi square test and contingency coefficient}

Where the SPPS.21.0 output is known as follows:

Table 3. Chi - Square test

\begin{tabular}{|c|c|c|c|}
\hline \multicolumn{4}{|c|}{ Chi-Square Tests } \\
\hline & Value & df & Asymp. Sig. (2-sided) \\
\hline Pearson Chi-Square & $12.869 \mathrm{a}$ & 3 & .005 \\
\hline Likelihood Ratio & 16,208 & 3 & .001 \\
\hline $\begin{array}{c}\text { Linear-by-Linear } \\
\text { Association }\end{array}$ & 11,007 & 1 & .001 \\
\hline $\mathrm{N}$ of Valid Cases & 59 & & \\
\hline
\end{tabular}

From the output above, it can be seen that: Person Chi-Square $=12,869$ where $\mathrm{df}=3$, sig. $=$ $0.005<0.05$. This suggests that there is a significant difference in the results of the student service ability test in the audio video learning group (experimental group) and the learning group using conventional methods (control). The existence of this significant difference, it can be said that the treatment in the form of the use of audiovisual learning methods has an effect on the level of ability to serve students. $\chi^{2}$ 


\begin{tabular}{|c|c|c|c|c|c|}
\hline & & Value & Asymp. Std. Errora & Approx. Tb & Approx. Sig. \\
\hline $\begin{array}{l}\text { Nominal by } \\
\text { Nominal }\end{array}$ & $\begin{array}{l}\text { Contingency } \\
\text { Coefficient }\end{array}$ & .423 & & & .005 \\
\hline $\begin{array}{l}\text { Interval by } \\
\text { Interval }\end{array}$ & Pearson's R & .436 & .103 & 3,654 & $.001 \mathrm{c}$ \\
\hline $\begin{array}{l}\text { Ordinal by } \\
\text { Ordinal }\end{array}$ & $\begin{array}{l}\text { Spearman } \\
\text { Correlation }\end{array}$ & .424 & .109 & 3,536 & $.001 \mathrm{c}$ \\
\hline \multicolumn{2}{|c|}{$\mathrm{N}$ of Valid Cases } & 59 & & & \\
\hline
\end{tabular}

From the results of the output above, it can be seen that: the contingency coefficient has a value of 0.423 , this significantly indicates that the magnitude of the influence of the use of audio video media on the improvement of student service ability is $42.3 \%$. This means that this influence is quite large, but there is still the influence of other variables, namely $57.7 \%$.

\section{c) Mean difference test}

This mean difference test aims to strengthen the data analysis performed using nonparametric statistics. In this testing technique, it is used to classify the class into the control class group and the experimental class. However, the data on the ability to serve students used numerical data which is ratio data, namely the data on the test results of the ability to serve students. With the help of SPSS.21 on the independent t-test menu, the output can be described as follows:

Table 5. Output SPPS.21.0: Mean of each group

\begin{tabular}{|c|c|c|c|c|c|c|c|}
\hline \multicolumn{8}{|c|}{ Group Statistics } \\
\hline & & \multirow[t]{3}{*}{ Klp } & \multirow[t]{3}{*}{ Statistics } & \multicolumn{4}{|c|}{ Bootstrapa } \\
\hline & & & & \multirow[t]{2}{*}{ Bias } & \multirow[t]{2}{*}{$\begin{array}{c}\text { Std. } \\
\text { Error }\end{array}$} & \multicolumn{2}{|c|}{$\begin{array}{c}\text { 95\% Confidence } \\
\text { Interval }\end{array}$} \\
\hline & & & & & & Lower & Upper \\
\hline \multirow[t]{8}{*}{ N_lyni } & knvs & $\mathrm{N}$ & 29 & & & & \\
\hline & & Mean & 76.0000 & -.0484 & 1.9450 & 72,2002 & 79.9665 \\
\hline & & Std. Deviation & 10.67708 & -.20754 & 1.26318 & 7.85121 & 12,93619 \\
\hline & & Std. Mean Error & 1.98268 & & & & \\
\hline & Ekp1 & $\mathrm{N}$ & 30 & & & & \\
\hline & & Mean & 85.1667 & .0352 & 1.6773 & 81.7189 & 88.4480 \\
\hline & & Std. Deviation & 8,85548 & -19555 & .71989 & 7.16657 & 10.08012 \\
\hline & & Std. Mean Error & 1.61678 & & & & \\
\hline
\end{tabular}

The control group obtained an average of 70.0 with the number of students as many as $\mathrm{N}=$ 29. and the experimental group obtained an average of 85.1667 with the number of students in this experimental group was $\mathrm{N}=30$.

Table 6. Output SPPS.21.0: independent t-test 
Independent Samples Test

\begin{tabular}{|c|c|c|c|c|c|c|c|c|c|c|}
\hline & \multicolumn{2}{|c|}{$\begin{array}{l}\text { Levene's Test for } \\
\text { Equality of } \\
\text { Variances } \\
\end{array}$} & \multicolumn{7}{|c|}{ t-test for Equality of Means } \\
\hline & & \multirow[b]{2}{*}{$\mathrm{F}$} & \multirow[b]{2}{*}{ Sig. } & \multirow[b]{2}{*}{$\mathrm{T}$} & \multirow[b]{2}{*}{ Df } & \multirow[b]{2}{*}{$\begin{array}{l}\text { Sig. (2- } \\
\text { tailed) }\end{array}$} & \multirow{2}{*}{$\begin{array}{l}\text { Mean } \\
\text { Differenc } \\
\mathrm{e}\end{array}$} & \multirow{2}{*}{$\begin{array}{l}\text { Std. Error } \\
\text { Differenc } \\
\mathrm{e}\end{array}$} & \multicolumn{2}{|c|}{$\begin{array}{l}95 \% \\
\text { Confidence } \\
\text { Interval of } \\
\text { the } \\
\text { Difference }\end{array}$} \\
\hline & & & & & & & & & $\begin{array}{l}\text { Lowe } \\
\mathrm{r}\end{array}$ & $\begin{array}{l}\text { Uppe } \\
\text { r }\end{array}$ \\
\hline Nelyni & $\begin{array}{l}\text { Equal } \\
\text { variances } \\
\text { assumed }\end{array}$ & .461 & .500 & $-3,595$ & 57 & .001 & -9.16667 & 2,55018 & $\begin{array}{r}14.27 \\
331\end{array}$ & $\begin{array}{r}4.06 \\
002\end{array}$ \\
\hline & $\begin{array}{l}\text { Equal } \\
\text { variances not } \\
\text { assumed }\end{array}$ & & & $-3,583$ & 54,396 & .001 & -9.16667 & 2,55832 & $\begin{array}{r}14.29 \\
494\end{array}$ & $\begin{array}{r}4.03 \\
839\end{array}$ \\
\hline
\end{tabular}

From the results of the table above it is known that the t-test coefficient value is -3.595 with a significance level of $0.001<0.05$, which means that there are differences in the results of the test of the ability to serve in the experimental group and the control group. In addition, the information that can be presented is that the results of the leven's test obtained a value of $\mathrm{F}=$ 0.461 with a significance level of $0.5>0.5$ which means that the distribution of data used in this mean difference test is homogeneous.

\subsection{Discussion}

In this study, the learning took place in two meetings, both the experimental class and the control class. At the first meeting, the lecturer gave material about A6's attitude in the process of excellent service. Then, the students were divided into small groups of 4-5 people. Lecturers gave small group assignments to discuss the Javanese philosophy they had known and applied to everyday life. The results of the discussion were presented in front of the class and discussion was held. At the second meeting, the lecturer gave material on how to cultivate A6's attitude in students and relate it to Javanese philosophy. For experiment class, the lecturer provided material using instructional videos, while in the control class the lecturer provided material with direct explanations and used power point media[5][6].

After the students watched a video about Javanese philosophy, the students held discussions in their groups to answer questions from the lecturers. Pretest was done at the beginning of the first meeting and post-test was given at the end of the second meeting. The pretest and post-test consisted of 25 questions which validity and reliability had been tested as in table 4.1 of validity and reliability test results which show that all questions are valid and reliable. Based on the test results of the ability to serve students in the control class, it shows that the majority of students are in the poor category. The experimental class shows that the majority of students are in the good category. Thus, the results of this study prove that there is an effect of the use of audio video on learning outcomes, namely the ability to serve students, as in previous research conducted by Zhang, D, et al [7][8].

With the video media, it makes it easier for students to absorb the material provided by the lecturer. Along with the development of the digital age, student learning attitudes have also changed. Theories related to student learning outcomes that already exist are very relevant to the results of the research that the author conducted. [9] The results showed that the class that used video media in learning (experiment) had a higher average score of learning outcomes than the class that did not use video media (control). In addition, there are more students who have 
high learning outcomes in classes whichuse video media compared to classes that don't use video media. Thus, the theories above which suggest the use of video media can affect student learning outcomes is proven.[10][4][11]

\section{Conclusion}

In accordance with the formulation and research objectives in the previous chapter, the final answer to this research is the following conclusions: There is an effect of the use of an audiovisual learning model on improving the students' ability to serve. The magnitude of the influence of the use of the audiovisual learning model on improving the ability to serve students in this study is $43.3 \%$

\section{Acknowledgements}

The author would like to thank the Ministry of Education and Culture for financial support to this research. State Polytechnic Of Madiun for support.

\section{References}

[1] M. C. Bier and D. Ph, What Works In Character Education : A research-driven guide for educators Character Education Partnership, no. February. 2005.

[2] G. Skaggs, "Relationships Between Implementing Character Education, Student Behavior, and Student Achievement," J. Adv. Acad., vol. 18, no. 1, pp. 82-114, 2006.

[3] E. M. Syafitri, F. Indrasari, N. Lisdiantini, H. F. Thousani, R. Muarief, and A. D. Setiawan, "Character Education Based-on Local Wisdom in Excellent Service Course," vol. 354, no. iCASTSS, pp. 365-368, 2019.

[4] H. M. Huang, U. Rauch, and S. S. Liaw, "Investigating learners' attitudes toward virtual reality learning environments: Based on a constructivist approach," Comput. Educ., vol. 55, no. 3, pp. 1171-1182, 2010.

[5] P. Anggraini, "Character and Local Wisdom-Based Instructional Model of Bahasa Indonesia in Vocational High Schools," J. Educ. Pract., vol. 8, no. 5, pp. 23-29, 2017.

[6] B. R. Lewis and V. W. Mitchell, "Defining and Measuring the Quality of Customer Service," Mark. Intell. Plan., vol. 8, no. 6, pp. 11-17, 1990.

[7] D. Zhang, L. Zhou, R. O. Briggs, and J. F. Nunamaker, "Instructional video in e-learning: Assessing the impact of interactive video on learning effectiveness," Inf. Manag., vol. 43, no. 1, pp. 15-27, 2006.

[8] E. Ribawati, "Pengaruh Penggunaan Media Video Terhadap Motivasi Dan Hasil Belajar Siswa," Candrasangkala J. Pendidik. dan Sej., vol. 1, no. 1, pp. 134-145, 2015.

[9] R. Johnston, "Towards a better understanding of service excellence," Manag. Serv. Qual. An Int. J., vol. 14, no. 2, pp. 129-133, 2004.

[10] B. A. Universitat Politècnica de Catalunya. Institut de Ciències de l'Educació. and M. M. Martínez, "Journal of technology and science education.," J. Technol. Sci. Educ., vol. 2, no. 1, pp. 1-3, 2011.

[11] M. Merkt, S. Weigand, A. Heier, and S. Schwan, "Learning with videos vs. learning with print: The role of interactive features," Learn. Instr., vol. 21, no. 6, pp. 687-704, 2011. 
